\title{
Optimization of productivity and quality of cucumber plants in protected ground
}

\author{
Tamara Oliva ${ }^{1}$, Elena Kolesnichenko ${ }^{1}$ and Tamara Morozova ${ }^{1}$ \\ ${ }^{1}$ Belgorod State Agrarian University named after V.Ya. Gorin, 1, Vavilova st., Maysky village, Belgorod region, \\ 308503, Russia
}

\begin{abstract}
The paper studies the effect of growth stimulants on morphometric indicators of cucumber plant growth and development in the phase of intensive vegetation and transition to fruiting. The study was carried out at LLC Agricultural Enterprise "Teplitsy Belogorya" on the parthenocarpic hybrid of cucumber Tristan F1. Within the scientific and production experiment the grown cucumber plants on cotton-mineral cubes with drip watering were additionally vegetatively treated with a humic fertilizer solution and Azosol 36 microfertilizer. Phenological observations were carried out and morphometric parameters were determined: plant height, stem and leaf weight, leaf area, root system weight. Under the influence of treatments, the leaf area and weight of cucumber leaves increased by an average of 20 and 17\%, respectively. It was established that vegetative treatment with the studied solutions allows partially controlling physiological processes and organogenesis of the greenhouse cucumber plant. The vegetative organs of the cucumber plant leaf, stem and root were found to exhibit different abilities to accumulate chemical elements within the two experiments. The series of element distribution in the natural substance of the plant vegetative organs are shown (in a decreasing amount, total nitrogen, phosphorus, potassium for a series: leaf - stem - root; calcium, magnesium, zinc, iron, manganese and copper for the series: root - leaf - stem). The use of the studied fertilizers increased the commercial quality of cucumber fruits. Button contained a higher amount of total sugar and vitamin C, were environmentally safe in terms of the content of nitrates and heavy metals (cadmium, lead, arsenic, mercury). The optimization of productivity and quality improvement of cucumber plants using biological humic fertilizer and chelate microfertilizer increased the average yield by $5.5 \%$ and the profitability of ecologically safe greenhouse vegetables by $3.3 \%$.
\end{abstract}

\section{Introduction}

The increase in the profitability of vegetable production of protected ground is often caused by the increase in the volume of production, but not by the increase in production efficiency. Therefore, the introduction of scientifically sound agricultural technologies for cultivating crops is relevant [1-4]. Selection and introduction of mineral solutions, as well as biological growth stimulants for different greenhouse crops with high degree of automation reduces the labor intensity of the main processes by an average of 2-2.5 times [5, 6]. When using stimulants, the development of the plant is accelerated, resistance to adverse environmental factors is increased. This allows inducing the genetic potential of productivity of modern varieties of greenhouse crops [7-8]. A typical example of biogenic stimulants is humic substances. Tests show that they reduce the energy consumption of the plant body to overcome the negative effect of xenobiotics and stimulate metabolism [9]. It was found that optimizing the productivity and yield of greenhouse vegetables is most effective in the integrated use of humates and mineral elements in chelate form. It should be noted that the use of environmentally friendly growth stimulants as an alternative to synthetic ones increases not only the quality of the output of protected ground, but also significantly improves the environmental situation of production itself, which corresponds to indicators and strategies for the sustainable development of the modern agricultural market.

The purpose of the study is to develop an optimal agricultural technology for cultivating parthenocarpic cucumber hybrid using biological humic fertilizer with growth-stimulating and adaptogene action, innovative chelate complexes of microelements that reduce stress from adverse hydrothermal conditions that improve the quality characteristics of the greenhouse plant when using cotton-mineral cubes and drip watering.

\section{Materials and methods}

The scientific and production experiment was carried out during the winter-spring crop rotation of 2015-2016 at LLC Agricultural Enterprise "Teplitsy Belogorya" in the educational and scientific laboratory of biotechnological research and in the accredited test laboratory of Belgorod State Agrarian University named after V.Ya. Gorin. The

\footnotetext{
* Corresponding author: olivatv@ mail.ru
} 
subject of the study was the parthenocarpic cucumber hybrid Tristan F-1 (by Enza Zaden, Holland). The hybrid is included in the State Register of the Russian Federation in the third photic zone for cultivation in winter-spring rotation. High-yielding, with stable fruiting. Fruits have good taste. The hybrid is resistant to real powdery mildew and is recommended for all types of greenhouses.

The experiments with Tristan F-1 cucumber hybrid were carried out in accordance with the generally accepted method of field experiment with vegetable crops in structures of protected ground according to Dospekhov B.A. Before sowing, cucumber seeds were soaked in a solution with a concentration of $0.01 \mathrm{mg} / \mathrm{l}$ of Azosol 36 chelate microfertilizer and in the solution of distilled water for 4 hours (in an amount of 700 pieces in each version). Mineral microfertilizer Azosol 36 is a chelate complex of biogenic elements of manganese, iron, magnesium, zinc, copper and boron, created on the basis of IDHA biodegradable complex (iminodiyantaric acid). Therefore, the elements do not go into forms inaccessible to the plant and are quickly absorbed by the body. The seeds were then planted into pre-nourished cotton-mineral cubes $(7 \times 7 \mathrm{~cm}$, Grodan). Substrate moisture was maintained at $75-89 \%$ of the lowest moisture capacity. Relative air humidity $-60-65 \%$. Light is needed for the development of seedlings: the first 2-3 days $-24 \mathrm{~h} /$ day, then $16 \mathrm{~h} /$ day.

The experiment scheme included the use of the following fertilizers: variant 1 - control using only nutrient solution according to the scheme of growing cucumbers in a greenhouse; variant 2 - nutrient solution for drip watering and additional vegetative treatment with Azosol 36 solution in the concentration of $0.1 \mathrm{mg} / \mathrm{l}$ and BelBio-3 biological fertilizer solution in the concentration of $0.001 \%$ of humic substances. The characteristics and composition of the humic fertilizer are described in previous publications [10]. Cucumber plants, in addition to the main nutrient solution of the drip watering system, were vegetatively treated with the studied solutions in the phases of appearance of the first leaf, formation of 3-4 leaves, after transferring the plants to the growth shop, after fifteen days to the phase of intensive growth, before flowering and to the phase of beginning of fruit formation.

The duration of observations was about 100 days (the period from sowing to harvesting). Phenological observations were made, in the formation phase of 6 cucumber leaf five plants were randomly selected from each variant to determine morphometric indicators (plant height, stem and leaf weight, leaf area, root system weight). According to conventional methods, biochemical analysis of samples of the root, stem, leaf and fruit of the cucumber plant was carried out. All studies with our participation were carried out at the Test Laboratory of Belgorod SAU. Dry matter was determined according to GOST 20851.4; nitrogen weight fraction - according to GOST 30181.1; weight fraction of potassium and calcium - according to GOST 32343 and GOST GOST 26570; phosphorus - according to GOST 26657; sugar - according to Bertrand, chlorophyll - by spectrophotometric method and Getri solution, vitamin C - by iodometric method, and nitrates according to GOST 29270. Microelements and toxic substances were determined by atomic absorption according to GOST 30692 and GOST 30178. Mathematical processing of data based on the results of studies and yields was carried out by the dispersion analysis using Excel in Microsoft Windows.

\section{Results and Discussion}

Greenhouse production of vegetables involves adverse situations for the growth and development of plants (temperature dynamics, changes in nutrient solution compositions, transfer of plants from the seedling shop to the growth shop, stimulation of fruit formation, a variety of diseases, etc.). The task was to develop techniques for stimulating the stage of juvenile plant development: the development of a seedling and the accumulation of vegetative mass sufficient to form flowers and fruits. Mass seedlings of Tristan F-1 cucumber hybrid were obtained on the 4th day after planting. Plants were sorted on that day (Table 1).

Table 1. Rejection of cucumber plants, $\%$.

\begin{tabular}{|c|c|c|}
\hline Indicator & Variant 1 & Variant 2 \\
\hline Rejection & 5.5 & 1.3 \\
\hline
\end{tabular}

The table shows that in the variant with soaking of cucumber seeds in a microfertilizer solution with a complex of chelate mineral elements, the rejection was significantly less (by 24\%). For the control this made 39 plants, for the experimental version - 2-9 plants. Tables 2 and 3 show the effect of microfertilizer and humic substances on the growth and development of vegetative organs of cucumber.

Table 2. Allocation of cucumber seedling phytomass into the 6-leaf phase.

\begin{tabular}{|l|c|c|}
\hline \multirow{2}{*}{ Indicator } & \multicolumn{2}{c|}{ Weight of plants and organs, $\mathrm{g}$} \\
\cline { 2 - 3 } & Variant 1 & Variant 2 \\
\hline Total weight & $112.04 \pm 1.62$ & $115.15 \pm 2.02$ \\
\hline Leaves & $42.31 \pm 1.34$ & $49.64 \pm 0.84$ \\
\hline Stem & $40.85 \pm 0.60$ & $41.51 \pm 0.55$ \\
\hline Root & $28.88 \pm 2.00$ & $24.00 \pm 0.88$ \\
\hline
\end{tabular}

Table 3. Metric characterization of cucumber seedlings in the 6-leaf phase.

\begin{tabular}{|l|c|c|}
\hline \multicolumn{1}{|c|}{ Indicators } & Variant 1 & Variant 2 \\
\hline Leaf area, $\mathrm{cm}^{2}$ & $383.97 \pm$ & $461.15 \pm$ \\
10.22 & 10.15 \\
\hline Leaf area to mass ratio, $\mathrm{cm}^{2} / \mathrm{g}$ & 9.1 & 9.3 \\
\hline Photosynthetic force, g/g & 0.38 & 0.43 \\
\hline $\begin{array}{l}\text { Ratio of stem mass to plant } \\
\text { mass, g/g }\end{array}$ & 0.37 & 0.36 \\
\hline Root to plant weight ratio, g/g & 0.26 & 0.21 \\
\hline
\end{tabular}

Tristan F-1 hybrid cucumber plants, which additionally received complex microfertilizers and humate with the main nutrient solution, grew together and developed correctly. By the period of plant transfer to the growth block, the height of cucumber plants was higher in variant 2 by on average 1.1 times compared to variant 1 , i.e. these plants began to be ahead of control 
by 2-3 days of development. The main constraints to plant development are the small leaf surface and the limited ability to assimilate. The tables show that plants of variant 2 , under the influence of vegetative treatments, increase the leaf surface and leaf weight by an average of $20 \%$ and $17 \%$, respectively. From the scientific literature it is known that juvenile seedlings are characterized by high content of auxin, which may form in young leaves. The studied preparations stimulated the development of plant leaves, and thus contributed to the absorption of light energy, which ultimately affected the qualitative and quantitative formation of the plant organism and crop.

Recently, the connection of photosynthesis with plant productivity has undergone an evolution. The idea is discussed that plant productivity is limited by transport processes and the activity of biosynthesis in organs that depend on the amount of assimilate substances that enter them. Table 4, 5 and 6 show the nutrient content of leaves, stem and root of Tristan F-1 cucumber hybrid under different test conditions.

Table 4. Average composition of cucumber leaf (in terms of raw material).

\begin{tabular}{|l|c|c|}
\hline \multicolumn{1}{|c|}{ Indicator } & Variant 1 & Variant 2 \\
\hline Moisture, $\%$ & $88.66 \pm 0.21$ & $88.39 \pm 0.12$ \\
\hline Crude ash,\% & $2.09 \pm 0.03$ & $2.06 \pm 0.03$ \\
\hline $\begin{array}{l}\text { Total } \\
\text { nitrogen,\% }\end{array}$ & $0.61 \pm 0.01$ & $0.64 \pm 0.01$ \\
\hline Protein, mg\% & $39.65 \pm 0.02$ & $41.60 \pm 0.02$ \\
\hline Phosphorus.\% & $0.094 \pm 0.001$ & $0.085 \pm 0.002$ \\
\hline Calcium,\% & $0.77 \pm 0.04$ & $0.44 \pm 0.03^{*}$ \\
\hline Potassium,\% & $0.45 \pm 0.01$ & $0.42 \pm 0.02$ \\
\hline Zinc, mg/kg & $7.05 \pm 0.01$ & $8.69 \pm 0.03 *$ \\
\hline Iron, mg/kg & $22.23 \pm 0.03$ & $21.13 \pm 0.03$ \\
\hline $\begin{array}{l}\text { Manganese, } \\
\text { mg/kg }\end{array}$ & $2.81 \pm 0.11$ & $3.12 \pm 0.01^{*}$ \\
\hline $\begin{array}{l}\text { Copper, } \\
\text { mg/kg }\end{array}$ & $3.82 \pm 0.05$ & $5.03 \pm 0.02 *$ \\
\hline $\begin{array}{l}\text { Magnesium, } \\
\text { mg/kg }\end{array}$ & $2.59 \pm 0.05$ & $3.06 \pm 0.03 *$ \\
\hline p $<0.05$ vs. control & & \\
\hline
\end{tabular}

Table 5. Average composition of cucumber stem (in terms of raw material).

\begin{tabular}{|l|c|c|}
\hline \multicolumn{1}{|c|}{ Indicator } & Variant 1 & Variant 2 \\
\hline Moisture,\% & $93.90 \pm 0.10$ & $94.29 \pm 0.10$ \\
\hline Crude ash,\% & $1.43 \pm 0.01$ & $1.32 \pm 0.02$ \\
\hline $\begin{array}{l}\text { Total } \\
\text { nitrogen,\% }\end{array}$ & $0.21 \pm 0.01$ & $0.18 \pm 0.01$ \\
\hline Protein, $\mathrm{mg} \%$ & $13.65 \pm 0.02$ & $11.70 \pm 0.01$ \\
\hline Phosphorus.\% & $0.043 \pm 0.003$ & $0.036 \pm 0.002$ \\
\hline Calcium,\% & $0.21 \pm 0.01$ & $0.17 \pm 0.02^{*}$ \\
\hline Potassium,\% & $0.38 \pm 0.02$ & $0.35 \pm 0.01$ \\
\hline Zinc, mg/kg & $3.43 \pm 0.03$ & $4.17 \pm 0.02^{*}$ \\
\hline Iron, mg/kg & $8.31 \pm 0.01$ & $14.03 \pm 0.03^{*}$ \\
\hline $\begin{array}{l}\text { Manganese, } \\
\mathrm{mg} / \mathrm{kg}\end{array}$ & $1.65 \pm 0.02$ & $2.38 \pm 0.02^{*}$ \\
\hline $\begin{array}{l}\text { Copper, } \\
\mathrm{mg} / \mathrm{kg}\end{array}$ & $3.75 \pm 0.03$ & $4.95 \pm 0.02^{*}$ \\
\hline
\end{tabular}

\begin{tabular}{l|l|l|}
\hline $\begin{array}{l}\text { Magnesium, } \\
\mathrm{mg} / \mathrm{kg}\end{array}$ & $0.64 \pm 0.04$ & $0.74 \pm 0.01^{*}$ \\
\hline & & \\
\hline $\mathrm{p}<0.05$ vs. control
\end{tabular}

Data from the tables confirm that plants from variant 2 accumulate more protein in the leaves (by $4.9 \%$ ) as a result of enhanced photosynthetic assimilation, and absorb more zinc - by $23.3 \%$, magnesium - by $18.2 \%$, manganese - by $11.0 \%$ and copper - by $31.7 \%$ from nutrient solutions. It is known that in a young plant cell, chlorophyll contains $10-12 \%$ magnesium, it acts as a competitor to calcium and potassium, and is involved in the formation of the structure of nucleic acids. Zinc activates carbonic anhydrase and helps to use carbon dioxide in the process of photosynthesis, participates in the formation of tryptophan and thus affects the synthesis of protein and phytohormones. Copper, which is present in large quantities in leaf chloroplasts, is part of most enzymes and increases resistance to stress. It is known from scientific literature that biogenic manganese accumulating in plant leaves increases sugar content and participates in its outflow from leaves. Vegetative organs of the cucumber plant: stem and root in two versions of the experiment showed different ability to accumulate certain elements.

Table 6. Average composition of cucumber root (in terms of raw material).

\begin{tabular}{|l|c|c|}
\hline \multicolumn{1}{|c|}{ Indicator } & Variant 1 & Variant 2 \\
\hline Moisture, $\%$ & $90.53 \pm 0.03$ & $89.67 \pm 0.03$ \\
\hline Crude ash, $\%$ & $6.95 \pm 0.02$ & $7.87 \pm 0.05$ \\
\hline Total nitrogen, $\%$ & $0.14 \pm 0.02$ & $0.15 \pm 0.01$ \\
\hline Protein, $\mathrm{mg} \%$ & $9.10 \pm 0.02$ & $9.75 \pm 0.01$ \\
\hline Phosphorus.\% & $0.034 \pm 0.001$ & $0.035 \pm 0.002$ \\
\hline Calcium, \% & $0.79 \pm 0.04$ & $1.01 \pm 0.06^{*}$ \\
\hline Potassium, $\%$ & $0.30 \pm 0.01$ & $0.26 \pm 0.01$ \\
\hline Zinc, $\mathrm{mg} / \mathrm{kg}$ & $23.26 \pm 0.02$ & $26.75 \pm 0.05^{*}$ \\
\hline Iron, mg/kg & $209.37 \pm 0.22$ & $241.83 \pm 0.33^{* *}$ \\
\hline $\begin{array}{l}\text { Manganese, } \\
\mathrm{mg} / \mathrm{kg}\end{array}$ & $88.94 \pm 0.22$ & $101.19 \pm 0.29^{*} *$ \\
\hline Copper, mg/kg & $11.96 \pm 0.36$ & $13.85 \pm 0.25^{*}$ \\
\hline $\begin{array}{l}\text { Magnesium, } \\
\mathrm{mg} / \mathrm{kg}\end{array}$ & $90.53 \pm 0.03$ & $89.67 \pm 0.03$ \\
\hline * $<0.05$ vs. control & & \\
\hline
\end{tabular}

There is the general trend of accumulation of iron, manganese, copper and zinc in these cucumber vegetative organs. The plant root selectively accumulated biogenic calcium, which contributes to the preservation of the integrity of cell membranes, provides tissue strength, and, according to literature, may reduce fruit spoilage during fruiting.

The series of distribution of elements in the natural matter of the cucumber plant, which was vegetatively fed with microelements in chelate form and stimulated the growth and development of humic substances, in descending order are as follows: in relation to total nitrogen, phosphorus, potassium: leaf - stem - root; calcium, magnesium, zinc, iron, manganese and copper: root - leaf - stem. So, the results show that additional vegetative nutrition of plants provides the cucumber needs for assimilants, which in the future will stimulate the productivity and yield of the greenhouse plant. 
The information criterion for estimating the amount of transition of chemicals and elements from the solution to plant organs is the accumulation factor. It was calculated as the ratio of the content of the element in the ash to the content in the nutrient solution for drip watering. The accumulation factor took into account that $300 \mathrm{ml}$ of nutrient solution was used to form $1 \mathrm{~g}$ of plant dry matter. The accumulation factor of chemical elements indicates that there are high needs for potassium, phosphorus, calcium, iron and magnesium for cucumber leaf tissues; manganese and zinc - for cucumber stem.

The calculations of the absorption of chemical elements by vegetative organs of cucumber plant are presented in Table 7.

Table 7. Average nutrient accumulation factors by vegetative organs of cucumber.

\begin{tabular}{|l|c|c|c|c|}
\hline \multirow{2}{*}{ Indicator } & \multicolumn{2}{|c|}{ Variant 1 } & \multicolumn{2}{c|}{ Variant 2 } \\
\cline { 2 - 5 } & stem & leaf & stem & leaf \\
\hline Nitrogen & 0.33 & 0.31 & 0.44 & 0.40 \\
\hline $\begin{array}{l}\text { Potassiu } \\
\text { m }\end{array}$ & 0.16 & 0.91 & 0.20 & 0.94 \\
\hline $\begin{array}{l}\text { Phospho } \\
\text { rus }\end{array}$ & 0.28 & 1.11 & 0.30 & 1.0 \\
\hline Calcium & 0.22 & 4.05 & 0.27 & 4.10 \\
\hline $\begin{array}{l}\text { Magnesi } \\
\text { um }\end{array}$ & 0.25 & 3.11 & 0.28 & 3.66 \\
\hline Copper & 2.42 & 3.00 & 1.80 & 4.32 \\
\hline $\begin{array}{l}\text { Mangan } \\
\text { ese }\end{array}$ & 3.95 & 1.51 & 5.95 & 1.86 \\
\hline Iron & 0.62 & 1.95 & 1.03 & 1.86 \\
\hline Zinc & 1.10 & 0.64 & 1.30 & 1.70 \\
\hline
\end{tabular}

The accumulation factor indicates that there are high needs for potassium, phosphorus, calcium, iron, copper and magnesium - for cucumber leaf tissues; manganese and zinc - for cucumber stem. The lack of these elements at different stages of plant growth may serve as a limiting factor in the development of the plant organism.

Spraying with micronutrient solution and humic fertilizer affected the ovary formation phase of Tristan F1 hybrid cucumber plants. Under the influence of the studied fertilizers, the number of ovaries on average on the plant of variant 2 was $5.5 \%$ more than in plants from the control variant 1 .

The first greens to appear gained weight faster in the experimental version compared to control. Additional use of the studied fertilizers improved the commercial quality of cucumber fruits (Table 8).

Table 8. Commercial quality of cucumber fruits.

\begin{tabular}{|l|c|c|}
\hline \multicolumn{1}{|c|}{ Indicator } & Variant 1 & Variant 2 \\
\hline Moisture,\% & $95.1 \pm 0.4$ & $94.6 \pm 0.2$ \\
\hline $\begin{array}{l}\text { Total } \\
\text { sugar,\% }\end{array}$ & $0.380 \pm 0.003$ & $0.432 \pm 0.001$ \\
\hline Vitamin C, & $7.30 \pm 0.23$ & $8.60 \pm 0.26$ \\
\hline
\end{tabular}

\begin{tabular}{|l|c|c|}
\hline $\mathrm{mg} \%$ & & $370 \pm 10$ \\
\hline $\begin{array}{l}\text { Nitrates, } \\
\mathrm{mg} / \mathrm{kg}\end{array}$ & $376 \pm 10$ & $0.160 \pm 0.004$ \\
\hline Lead, mg/kg & $0.180 \pm 0.004$ & $0.014 \pm 0.002$ \\
\hline $\begin{array}{l}\text { Cadmium, } \\
\mathrm{mg} / \mathrm{kg}\end{array}$ & $0.014 \pm 0.002$ & not found \\
\hline $\begin{array}{l}\text { Mercury, } \\
\mathrm{mg} / \mathrm{kg}\end{array}$ & not found & not found \\
\hline $\begin{array}{l}\text { Arsenic, } \\
\mathrm{mg} / \mathrm{kg}\end{array}$ & not found & \\
\hline
\end{tabular}

The total amount of sugar and vitamin $\mathrm{C}$ was higher in the cucumber greens from variant 2 by an average of 13.6 and $17.8 \%$, respectively, compared to the control. The use of feedstuffs did not affect the accumulation of nitrates and toxic metals, which made it possible to grow environmentally friendly products. The level of nitrates for cucumbers of protected grounds did not exceed the permissible values of $400 \mathrm{mg} / \mathrm{kg}$.

The yield of Tristan F-1 hybrid cucumber in variant 2 was an average of $5.5 \%$ higher than the control variant. That is, in the production experiment from the studied area in the second experiment it was possible to obtain $308 \mathrm{~kg}$ of high-quality commodity products more compared to control. The calculations showed that the use of humic fertilizer with a complex of microelements in chelate form increases the profitability of greenhouse cucumbers by an average of $3.3 \%$ (Table 9 ).

Table 9. Cost-effectiveness of cucumber production.

\begin{tabular}{|l|c|c|}
\hline \multicolumn{1}{|c|}{ Indicator } & Variant 1 & Variant 2 \\
\hline Yield, kg/sq.m. & 18.0 & 19.0 \\
\hline $\begin{array}{l}\text { Purchase price, } \\
1 \mathrm{~kg} / \text { rub. }\end{array}$ & 100 & 100 \\
\hline $\begin{array}{l}\text { Cost of production, } \\
\text { thousand rubles/t }\end{array}$ & 1800 & 1900 \\
\hline $\begin{array}{l}\text { Costs, thousand } \\
\text { rubles. }\end{array}$ & 1493 & 1535 \\
\hline $\begin{array}{l}\text { Profit, thousand } \\
\text { rubles. }\end{array}$ & 307 & 365 \\
\hline Profitability,\% & 20.5 & 23.8 \\
\hline
\end{tabular}

\section{Conclusion}

It was found that soaking seeds and vegetative treatment of Tristan F-1 hybrid cucumber with the studied solutions of chelate microfertilizer and humic fertilizer significantly reduce plant rejection after seedlings, affect growth intensity, leaf surface and leaf weight development, increase assimilation and accumulation of protein and biogenic elements in tissues. In other words, the vegetative treatment of cucumber plants with environmentally safe humic substances with a complex of available microelements allowed partially controlling the physiological processes of Tristan F-1 cucumber hybrid plants in the field of effective absorption of light energy, increasing the photosynthetic force of the plant, 
accumulation of nutrients, increasing fruit formation and increasing yield. Thus, the study made it possible to determine the optimal methods for growing resourcesaving environmentally safe technology for cultivating cucumber greenhouse crop on a small-volume substrate of cotton-mineral cubes using drip dosed watering.

\section{References}

1. S.N. Aleinik, A.F. Dorofeev, A.V. Akibchin, S.A. Linkov, A.A. Melentiev, Journal of Critical Reviews, 7, 9, 2174-2182 (2020).

2. A.V. Turianskii, A.F. Dorofeev, A.V. Akibchin, S.A. Linkov, A.G. Stupakov, Research Journal of Pharmaceutical, Biological and Chemical Sciences, 9, 5, 1836-1845 (2018).

3. S.A. Linkov, A.V. Akinchin, E.Yu. Kolesnichenko, T.S. Morozova, Innovations in the agro-industrial complex: problems and prospects, 4 (28), 150-161 (2020).

4. A.V. Akinchin, L.V. Levshakov, S.A. Linkov, V.V. Kim, V.V. Gorbunov, Bulletin of Kursk State Agricultural Academy, 9, 16-21 (2017).

5. A.S.Shulpekov, N.V. Kotsareva, O.N. Shabetya, Bulletin of Kursk State Agricultural Academy, 8, 109-115 (2018).

6. I.Ya. Pigorev, N.V. Dolgopalova, Bulletin of Kursk State Agricultural Academy, 4, 58-61 (2018).

7. I.Ya. Pigorev, O.V. Gryaznova, N.V. Volobueva, Bulletin of Kursk State Agricultural Academy, 9, 22-30 (2020).

8. I.Ya. Pigorev, O.V. Nikitina, A.I. Trubnikov, Bulletin of Kursk State Agricultural Academy, 2, 17-23 (2021).

9. T.V. Oliva, Successes of modern science, 3, 10, 94-98 (2016).

10. T.V. Oliva, S.D. Litsukov, S.I. Panin, L.A. Manokhina, Successes of modern natural science, 12, 66-71 (2017). 